\title{
New Perspectives on Old Patterns: Forced Migration of Haitians in the Dominican Republic
}

\author{
Laurel Fletcher and Timothy Miller
}

This unique, interdisciplinary study utilises demographic data as well as interviews to identify patterns of the forced migration and experiences of Haitians and Dominicans of Haitian descent who left the Dominican Republic and entered Haiti between August 1999 and July 2000. While forced migration of Haitians from the Dominican Republic is the subject of reports and international legal proceedings, there has been little quantitative data on this sensitive issue. This study offers the first statistical analysis of migration flows through a demographic assessment of this vulnerable population. We present several key findings regarding the patterns in the outflow, the characteristics of the population, and the treatment of those expelled by Dominican government officials. Our research indicates that those leaving the country are not afforded due process and frequently suffer abuses at the hands of government officials. These findings challenge many prevailing assumptions about the profile and treatment of this population. The study proposes measures to improve the migration system between the two countries so as to reduce the vulnerability to human rights deprivations of Haitians in the Dominican Republic.

Keywords: Forced Migration; Haitian Migrants; Dominican Republic; Human Rights

\section{Introduction and Research Questions}

Haitian migrants to the Dominican Republic are received ambivalently. In spite of the country's reliance on Haitian labour, the Dominican government has initiated large-scale expulsions of Haitians and Dominicans of Haitian descent from the country on three occasions in the past decade-in 1991, 1996-97 and 1999 (see Inter-American Commission on Human Rights 1991, 1999, 2001; Inter-American

Laurel Fletcher is Acting Clinical Professor at the University of California, Berkeley School of Law (Boalt Hall). Timothy Miller is a Researcher in the Demography Department, University of California, Berkeley. E-mail: lef@law.berkeley.edu

ISSN 1369-183X print/ISSN 1469-9451 online/04/040659-21 @ 2004 Taylor \& Francis Ltd DOI: $10.1080 / 13691830410001699504$

Carfax Publishing 
Court on Human Rights 2000). These episodes of collective, mass expulsion suggest the existence of a Dominican state policy and practice that may cause mass dislocation and human suffering. Though Dominican authorities officially describe this process as one of legal 'repatriation' of unauthorised migrants, the reported lack of individualised adjudication and the large numbers of individuals affected lead us to describe these incidents as collective, mass expulsions.

While scholars have focused on the inflows of Haitian migration and documented the particular vulnerabilities of this population, this study examines the outflow of Haitians and Dominicans of Haitian descent (Catanese 1999; Martinez 1995; Murphy 1991). In light of the economic and political factors that encourage Haitian migration to the Dominican Republic as well as the profile of these migrants, we believe the Haitian population in the Dominican Republic is vulnerable to human rights abuses. Poor, frequently without legal status, and socially isolated, Haitians in the Dominican Republic have little opportunity to organise and assert their rights. The United Nations has noted that many large-scale migrations around the world have been 'accompanied by increased instances of racism and xenophobia' (UN High Commissioner for Human Rights 2000). And migrants frequently are subject to violence, physical injury, threats and intimidation by public officials as well as private individuals, groups or institutions (UN General Assembly 1990). ${ }^{1}$ We initiated this study of the patterns of forced migration and experiences of Haitians and Dominicans of Haitian descent who left the Dominican Republic during the period August 1999-July 2000 to increase knowledge regarding the links between migration flows and human rights abuses. The study examines the following areas:

- What are the demographic characteristics of the outflow of forced migrants from the Dominican Republic?

- How do Dominican officials treat those subject to deportation, and what types of procedure do officials follow in determining which and how Haitians and Dominicans of Haitian descent are removed from the country?

- How do Dominican practices of deportation and expulsion affect families?

The next part of the paper contains historical and legal background regarding Dominican migration policy regarding Haitians. This is followed by an outline of the study methodology. We then present the findings of the study, with subsequent analysis. The study leads us to identify several antecedents to expulsion including the history and prevalence of anti-Haitian sentiment, power relations between Haiti and the Dominican Republic, and the political economy of Haitian migration.

\section{Background}

The development of the sugar cane industry after World War I and the use of Haitian labour in this sector have shaped the migration patterns of Haitians to the Dominican Republic. The United States occupied the Dominican Republic from 1916 to 1924. The destruction of the European beet-sugar industry during World War I created the opportunity for the Dominican Republic to become a major sugar 
producer. In order to satisfy the demand for labour, the United States initiated the practice of recruiting Haitians to work on Dominican sugar plantations.

Reliance on Haitian labour in the sugar industry continued after the United States withdrew from the country, and Haitians, though poorly paid and working in often harsh conditions, became a stable supply of workers. ${ }^{2}$ With the nationalisation of the sugar industry in the 1950s, President Trujillo formalised Haiti's supply of labourers. In 1952, Trujillo signed the Convenio, the first bilateral labour agreement with Haiti which contracted the Haitian government to provide thousands of Haitian workers to perform seasonal labour in the Dominican cane fields. The agreement remained in effect until 1986, when the Haitian dictator 'Baby Doc' Duvalier relinquished power and fled the country (Ferguson 1992).

Political instability and economic deterioration have continued to affect Haiti since the end of the Duvalier regime. Haitians are increasingly willing to leave their homes in search of employment in the Dominican Republic. In the late 1990s, official estimates of the number of Haitians living permanently in the Dominican Republic ranged between 500,000 and 700,000 (Inter-American Commission on Human Rights 1999). Once employed almost exclusively in the sugar industry, Haitians now make up large parts of the workforce in other agriculture sectors, such as coffee and rice.

Researchers rely on various migration theories to explain the outflows of Haitians to the Republic. Some attribute the presence of Haitians in the Dominican Republic primarily to economic and political relations as well as to labour trafficking between the two countries (Corten and Duarte 1995). John Salt (2001) has documented the role government officials play in this system. Many promote Haitian migration by facilitating the entry of Haitian workers-including those who enter without legal authorisation - and thus profit from this regime. Salt argues that the border between Haiti and the Dominican Republic constitutes primarily an economic, not legal, obstacle. Migrant traffic is recognised as an industry... where it is possible to identify vested interests which seek to develop, manage and promote migration flows (Salt 2001: 106).

Despite mechanisms to facilitate entry, several aspects of the population of Haitians migrating to the Dominican Republic inhibit this community from flourishing. First, Haitian cane cutters migrate from rural areas in Haiti to rural areas in the Dominican Republic, and from a developing country to a developing country. This contradicts the usual labour migration patterns in which migrants travel from rural to urban areas and from developing countries to industrialised nations. Second, unlike most migrants who tend to have resources, Haitian migrants are among the poorest of the poor. Finally, Haitian migrant networks are not well developed in the Dominican Republic. Thus migrants do not receive the cultural, social and economic support that facilitates and maintains communities.

Despite Haitians' prevalence in the workforce, Dominican authorities frequently deport them on the grounds that the migrant workers lack legal status. Since international law recognises the sovereign right of nations to regulate their borders, the manner in which authorities carry out deportations raises the question 'What are 
the applicable legal norms that govern state practice?' International standards regarding judicial guarantees and protection are well-established and apply to the determination of the legal status and deportability of Haitians in the Dominican Republic. In particular, it is well-settled that Articles 8 (the right to a fair trial) and 25 (right to judicial protection) of the American Convention on Human Rights establish minimal due process protections that apply to deportation proceedings. These are broad principles that provide the foundation for, but do not articulate the specific measures that will ensure, fair deportation adjudication. The Special Rapporteur on Migrant Workers for the Inter-American Commission for Human Rights (the enforcement body for the Convention) noted the absence of consensus on norms and practices that states adopt in treating immigrants and opined that, in light of the nature of the rights at stake in expulsion proceedings, states should provide several guarantees (UN High Commissioner for Human Rights 2001).

In addition, the prohibition against collective expulsions is explicitly provided for in international instruments, including Article 22(9) of the American Convention on Human Rights (freedom of movement). The Special Rapporteur noted that collective expulsions are not determined by any particular number of persons, but the term encompasses those instances in which the decision to expel is not based on an individualised basis, but on 'group considerations' (UN High Commissioner for Human Rights 2001: para 97 (5)). Therefore, the size of the group does not determine whether expulsions legally are deemed collective, rather states are obligated to 'judge each case of expulsion or deportation individually'.

Dominican law provides those subject to deportation with an opportunity to oppose their removal. In practice, migration inspectors conduct deportations. According to the Director General of Migration, officers do not carry guns and do not use physical force during repatriations. In addition to domestic law, Dominican migration is regulated by the 'Protocol of Understanding' which the Dominican and Haitian governments signed after the 1999 expulsions. This agreement establishes additional procedures regulating the time, place and manner of deportation. Further, the agreement contains a number of provisions regarding the substantive treatment of Haitians subject to repatriation. For example, Dominican authorities are to prevent family separations in the process of deportations. The agreement provides that Dominican officials will endeavour to keep those repatriated together with their belongings, and to return to individuals any non-fraudulent documentation they presented. In sum, domestic laws and regulations establish a range of normative protections to Haitians subject to deportation.

\section{Study Design and Methodology}

We employed qualitative and quantitative methods to conduct the study. Researchers interviewed key informants and expulsion victims, and relied on narrative responses to a survey instrument administered to expellees. These materials provide rich data about the topic. We also utilised available statistical information to provide quantitative information about this social phenomenon, thereby providing data not 
discernable through observation or other methods. Finally, we employed demographic analysis to construct a clearer understanding of the patterns of forced migration.

Researchers interviewed 24 key informants including academics in Haiti and the Dominican Republic studying migration issues, representatives of non-governmental organisations (NGOs) working with the affected populations, Haitian and Dominican migration officials, and private Dominican companies that employ Haitian workers. Interview subjects were identified through prior contacts with NGOs working on Haitian issues. Semi-structured interviews were also conducted with 13 victims who had been expelled from the Dominican Republic to Haiti. ${ }^{3}$

The statistical data are based on an analysis of administrative records maintained by the Groupe d'Appui aux Refugiés et Repatriés (GARR), an aid group working at the major southern border crossings, and by Haiti's Office National de la Migration (ONM) which maintains an office in Ouanaminthe at the main border crossing in the north. These data are a sample of the flow of expellees from the Dominican Republic. They provide us with a statistical profile of the characteristics of these expellees, but they do not inform us as to the total numbers expelled. There is no reliable source for such counts.

GARR collected data on expellees in a three-page questionnaire. We analysed a total of 674 questionnaires administered to those expelled between August 1999 and December 2000. ONM recorded basic information (name, age, profession, etc.) for each expellee. We analysed 2,156 entries recorded between November 1999 and July 2000. The data sets are not uniform in content. Each covers different time periods and locations, and the questions asked or information recorded about those crossing the border varies. Table 1 presents the main characteristics of the two surveys by ONM and GARR, and provides the template for the first part of our discussion of findings.

\section{Findings \\ Demographic Assessment}

The population appears to be overwhelmingly male and concentrated in the age range 20-40. According to ONM data, about 80 per cent of those expelled are men. About half are below age 27. About 8 per cent are children below age 15 and 2 per cent are older adults over age 60. About 4 per cent were born in the Dominican Republic. Most of the adults have lived for at least two years in the Dominican Republic. The data show that levels of education, as indicated by the ability to sign one's name, are quite low among respondents, with approximately half of expellees able to do so. Lower rates are found among women and adults over 40 years old. Data from ONM also show that the vast majority of men deported were working in agriculture. GARR data also show men primarily employed in agriculture, but with significant proportions in construction and factory jobs. In the GARR surveys, the percentage of children (under 14 years) is 19 per cent and 3 per cent are elders aged 
Table 1. Characteristics of those expelled from the Dominican Republic (DR)

\begin{tabular}{|c|c|c|}
\hline & ONM & GARR \\
\hline Number of respondents & 2,156 & 674 \\
\hline Dates of expulsions & $\begin{array}{l}\text { November } 1999 \text { to } \\
\text { July } 2000\end{array}$ & $\begin{array}{l}\text { August } 1999 \text { to } \\
\text { December } 2000\end{array}$ \\
\hline $\begin{array}{l}\text { Peak months of expulsions (and } \\
\text { number expelled) }\end{array}$ & $\begin{array}{l}\text { November } 1999(498) \\
\quad \text { March } 2000(852)\end{array}$ & November 1999 (392) \\
\hline Per cent female (over age 15) & $21^{\star}$ & $29^{*}$ \\
\hline Per cent under age 15 & $8^{*}$ & $5^{\star}$ or $19 \dagger$ \\
\hline Per cent over age 60 & $2^{*}$ & $4^{*}$ or $3 \dagger$ \\
\hline Median age in years & $27^{*}$ & $30^{*}$ \\
\hline Per cent born in DR & 4 & 5 or $8 \dagger$ \\
\hline $\begin{array}{l}\text { Per cent living for at least two } \\
\text { years in DR } \\
\text { Mean number of years lived in } \\
\text { DR (GARR) and }\end{array}$ & $51^{\star}$ & $77^{\star}$ \\
\hline $\begin{array}{l}\text { Mean number of years since last } \\
\text { entered DR (ONM) }\end{array}$ & $3.9^{*}$ & $8.3^{\star}$ \\
\hline
\end{tabular}

* Means differ at $\mathrm{p}<0.05$ in t-test comparison.

$\dagger$ The population count includes an estimate of the number of children accompanying parents based on parental questionnaires, rather than child questionnaires.

60 and older. The share of deportees born in the Dominican Republic is 8 per cent, much higher than in the ONM data, reflecting the greater proportion of children found in the GARR data. ${ }^{4}$

The GARR data also provide us with information on the number of children (whether deported or not). Women aged 20-39 report an aggregate of 358 children, or about 2.8 children per woman. This is consistent with population data from Haiti which show a ratio of children aged 0-14 to women aged 20-39 of 3.0. The Haitian women living in the Dominican Republic appear to be quite similar to those living in Haiti, based on fertility levels. The average number of children deported per woman (1.5) is less than the average number of children per woman (2.8) because some women are deported, leaving behind their children in the Dominican Republic (18 per cent) and some women were living in the Dominican Republic without their children (22 per cent).

The other notable difference between ONM and GARR data is the length of time deportees lived in the Dominican Republic prior to deportation. GARR data show an average of 8.3 years, twice that of ONM. This might simply reflect a difference in the migration flows measured by ONM and GARR. GARR may be counting more settled immigrants (this is also consistent with the finding that GARR counts more families). On the other hand, this may also reflect a difference in the wording of the questions in the two surveys. ONM asks for the date of entry into the Dominican Republic, while GARR asks how long the respondent has lived in the Dominican Republic. It is quite possible that many of those interviewed by ONM may be listing their date of most recent entry rather than when they first entered the Dominican Republic. For the vast majority, this was their first expulsion from the country. 
Victim testimony and key informants also indicate that Dominican officials expel long-term Haitian residents. NGOs on both sides of the border maintain that the Dominican government targets long-term Haitian residents for expulsion to disrupt communities and to prevent Haitians from becoming a permanent presence in the country. One NGO representative explained that the Dominican government raided an entire batey community ${ }^{5}$ and sought to expel its Haitian residents after the factory in which many were employed had closed, and presumably their labour was no longer needed in the local economy.

\section{Manner of Expulsion}

Data from GARR provide us with both direct and indirect information on the process of expulsion. For the vast majority ( 88 per cent) this represented their first repatriation to Haiti. Most ( 88 per cent) were arrested. Of those arrested, 39 per cent report being arrested in a batey, 58 per cent outside a batey, and 3 per cent at work. Expellees report being arrested in public places, while shopping, walking on the street, going to or from church, taking a bath, on the way to the hospital and even one woman in labour. Similarly, arrests at homes were executed in summary fashion. Interviews with victims suggest that Dominican officials assume that anybody whom they identify as Haitian is subject to summary arrest and expulsion.

About one-third were imprisoned for a few days prior to deportation. About 10 per cent report they were beaten. Being pushed, shoved, and hit with rifle butts were the most common forms of physical abuse. Other expellees were subject to racist or derogatory comments by Dominican officials. Few had documents: 1 per cent with Haitian passports, 6 per cent with Haitian identification cards, and 4 per cent with Dominican Republic identification cards.

In addition, indirect information on the nature of the expulsions is provided by data on family separations and property left behind. The majority of those deported were married: 66 per cent of men and 86 per cent of women. About one-third of men were unmarried, another third were married but their wives were living in Haiti, and about one-third were married and residing with their spouse in the Dominican Republic prior to expulsion. Women were more likely to be married and more likely to be living with their husbands than men. Significant numbers of deportees were separated from their spouses: 13 per cent of men and 19 per cent of women.

Overall about 16 per cent of deportees were separated from their children who remained in the Dominican Republic. In the majority of cases (62 per cent), these children were apparently in the care of the other spouse. We do not know who cared for the children in the other 38 per cent of cases in which no parent remained in the Dominican Republic. In 20 per cent of the cases, the deported parent was unmarried. In 14 per cent of the cases, the deported parent lived in the Dominican Republic while his or her spouse lived in Haiti. And in 3 per cent of the cases, both parents were deported at the same time, leaving their children behind.

The vast majority of expelled adults (78 per cent) reported leaving behind 
property (in the form of wages, house, animals, and gardens) — wages (46 per cent), animals (45 per cent), gardens (47 per cent) and houses (28 per cent). Based on interview comments, we find an additional 9 per cent reported leaving behind 'belongings', rather than property per se. About 15 per cent of interviewer comments reported the expellee arrived 'empty handed'.

\section{Maps of Expulsions}

In the GARR data, respondents reported where they had been working in the Dominican Republic when they were expelled. We matched these place-names to latitude and longitude coordinates provided by the United States National Imagery and Mapping Agency (NIMA). We were able to match 39 per cent (or 134) of the place-names representing the locations of 43 per cent of expellees. Occasionally, places share a common name. For example, Santo Domingo is the capital of the Dominican Republic and is also the name of two small towns located in the mountains. In these cases, we selected the city with the lowest altitude. Most of the expulsions recorded in the GARR data occurred in November 1999. Figure 1 shows that the expulsions (mapped as circles) occurred throughout the country. Figure 1 also shows (as dots) the location of 462 bateys in the Dominican Republic (based on place-names from NIMA with 'Bateye' in the title). As is evident, bateys are widespread throughout the country. The expulsion map shows a close correspondence with these bateys as well as with the main towns in the Dominican Republic. The main conclusion from Figure 1 is that expulsions were widespread throughout the country and not limited to border areas. Official Dominican Republic government data confirm this pattern of widespread expulsions with six provinces reporting expulsions in November 1999: Santiago, 1,067; Higuey, 739; Contanza, 383; Pedernales, 354; La Vega, 252; Santo Domingo, 188 (Dirección General de Migración 2000).

Based on key informant interviews, there was some indication that the Dominican Republic was involved in 'repatriation redirection', in which officials intentionally repatriated expellees removed from the north of the Dominican Republic through the southern border crossing and vice versa. Key informants attributed this process to a punitive desire by state officials to disrupt migration patterns and deter unregulated migration from Haiti. The GARR data collected from the southern border crossings lends support to this hypothesis. As is evident in the expulsion maps, significant numbers of expellees are arrested in the north of the Dominican Republic and expelled in the south. Dividing the country into three major regions defined by 19 latitude and -70.2 longitude, we find 43 per cent of expulsions from the south, 48 per cent from the east, and 9 per cent from the north.

\section{Timing of Expulsions}

From the data we observe peaks in deportations for the months of November 1999 and March 2000. The November 1999 peak corresponds to press and other reports 


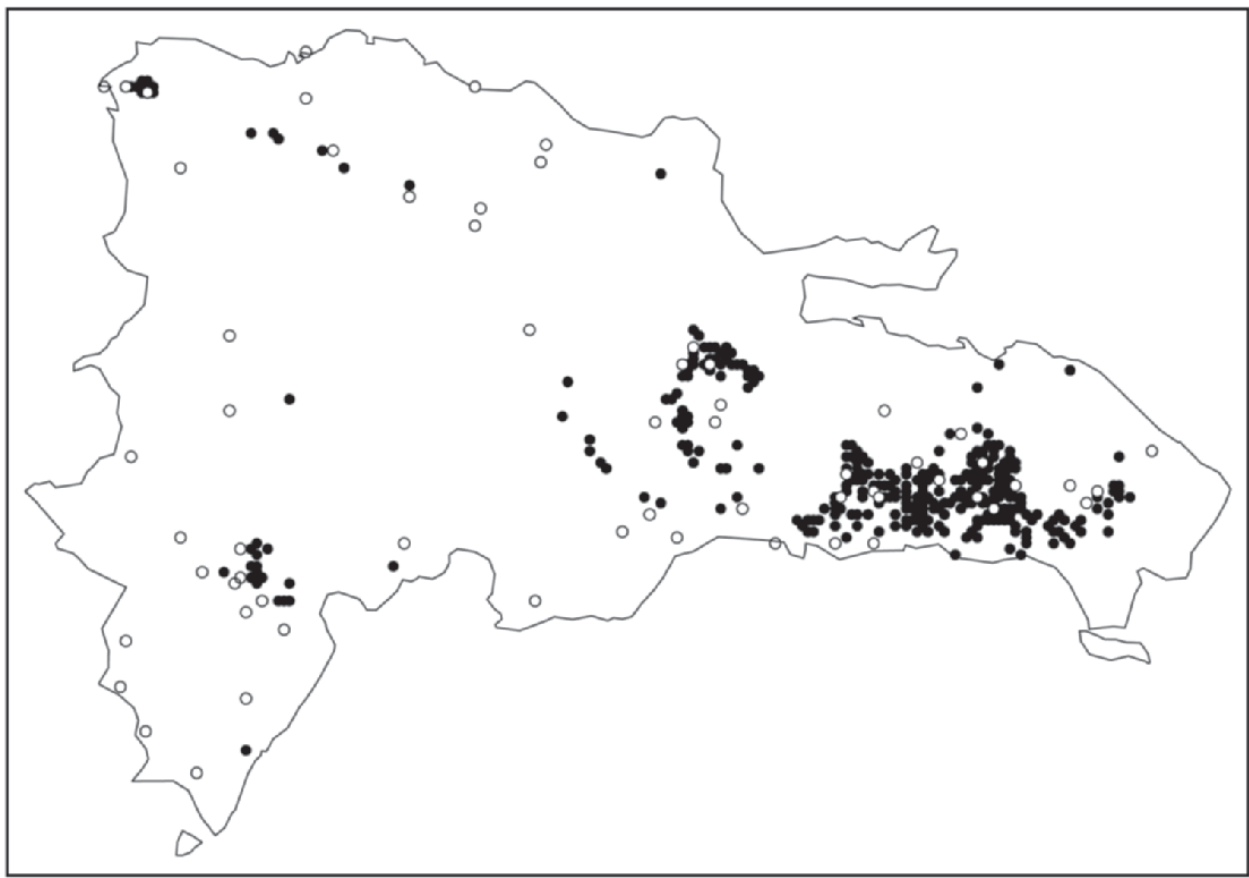

Figure 1. Where deportees lived (circles) and bateye locations (dots) in the Dominican Republic.

of mass expulsions. Tables 2 and 3, based on ONM and GARR data respectively, show that the composition of deportees changes during this period: more families and more long-term residents are deported. The data on these tables is self-explanatory, hence there is no need for detailed discussion. But particularly significant is the large reduction in the percentage of deportees who spend some time in prison. During the November 1999 mass expulsions, 22 per cent of deportees reported being imprisoned during their deportation, much lower than the 55 per cent observed

Table 2. Comparison of expulsions during peak periods of November 1999 and March 2000, ONM data

\begin{tabular}{lccc}
\hline & ONM Nov 1999 & ONM Mar 2000 & ONM Non-peak \\
\hline Number of respondents & 498 & 852 & 806 \\
Per cent female & $38^{\star}$ & $15^{\star}$ & $20^{\star}$ \\
Per cent under age 15 & $16^{\star}$ & $7^{\star}$ & $5^{\star}$ \\
Per cent over age 60 & 2 & 1 & 3 \\
Mean age in years & $26.5^{\star}$ & $27.1^{\star}$ & $29.5^{\star}$ \\
Per cent born in DR & $8^{\star}$ & $3^{\star}$ & $2^{\star}$ \\
Per cent living for at least two years & $45^{\star}$ & $58^{\star}$ & $48^{\star}$ \\
in DR & & & $3.2^{\star}$ \\
Mean number of years living in DR & $4.3^{\star}$ & & $3.3^{\star}$ \\
\hline
\end{tabular}

* Means differ at $\mathrm{p}<0.05$ in F-test comparison. 
Table 3. Comparison of expulsions during peak (November 1999) and non-peak periods, GARR data

\begin{tabular}{lcc}
\hline $\begin{array}{l}\text { All figures are per cent unless stated } \\
\text { otherwise }\end{array}$ & $\begin{array}{c}\text { GARR } \\
\text { Nov } 1999\end{array}$ & $\begin{array}{c}\text { GARR } \\
\text { non-peak }\end{array}$ \\
\hline Number of respondents & 392 & 282 \\
Female & $34^{\star}$ & $25^{\star}$ \\
Under age 15 & $21^{\star}$ & $14^{*}$ \\
Over age 60 & 4 & 3 \\
Mean age in years & 31.2 & 31.4 \\
Born in DR & 8 & 9 \\
Living for at least two years in DR & $80^{\star}$ & $73^{\star}$ \\
Mean number of years living in DR & $9.1^{*}$ & $7.2^{\star}$ \\
Arrested & $97^{\star}$ & $93^{\star}$ \\
In prison & $22^{\star}$ & $55^{\star}$ \\
Possess DR ID Card & 4 & 3 \\
Possess Haiti ID Card & 5 & 6 \\
Possess Haiti passport & 1 & 1 \\
Beaten & 12 & 9 \\
Separated from spouse & 18 & 16 \\
Separated from children & 15 & 17 \\
Wages left in DR & $39^{\star}$ & $50^{\star}$ \\
House left in DR & $22^{\star}$ & $35^{\star}$ \\
Garden left in DR & 44 & 46 \\
Animals left in DR & 44 & 44 \\
First repatriation & $87^{\star}$ & $94^{*}$ \\
Worked in agriculture & 49 & 49 \\
Worked in construction & $12^{\star}$ & $21^{\star}$ \\
Worked in selling & 13 & 14 \\
Worked in factory & $19^{*}$ & $13^{*}$ \\
Worked in housekeeping & 9 & 7 \\
\hline
\end{tabular}

* Means differ at $\mathrm{p}<0.05$ in the t-test comparison.

during other months (Table 3). This may be an indication of the 'system' breaking down under the strain of mass expulsions, with deportees taken directly to the border rather than being held in prisons.

Qualitative data indicate that the conditions under which expellees were detained are inadequate; expellees report frequently they received little food and water and were subject to arbitrary treatment by Dominican authorities. Similarly, conditions under which expellees were transported were harsh and degrading. Several victims reported that officials forced them to remain on the bus for hours or days at a time.

Official Dominican Republic statistics report about 17,000 deportations in 1999. These are broken down by province and month (Dirección General de Migración 2000). For many provinces the deportations appear to be sporadic, with many months without deportations. This is either due to sporadic reports or to sporadic deportations, or some combination of the two. If it is due to sporadic reports, this suggests that the true number of deportees is much higher. If it reflects sporadic deportations, this could be caused by the seasonal fluctuations in migrants to various provinces (deportations rise and fall in response to fluctuations in migration) or it 
could be caused by fluctuations in enforcement (officials decide to 'crack down' in a particular province)

\section{Interaction with Government Officials}

Data from the Dominican government indicates that migration officials have little contact with deportees. We observed some 'age heaping' on ages 20, 25, 30, 35, 40 and 45 in the Dominican data. ${ }^{6}$ Data from the Haitian ONM from the same period shows no such heaping. This is significant as it suggests that the Dominican government may not be affording due process to individuals it removes. The testimony of victims and other key informants corroborates this lack of individualised treatment by Dominican migration officials. For example, none of the expellee victims interviewed reported any meaningful opportunity to challenge his or her forced removal from the country. Victims and key informants also reported that a variety of Dominican agencies conduct expulsions. Victims identified the agency involved based on the uniforms and weapons of those carrying out the expulsions. Key informants noted that the army is closely involved in migration affairs and frequently conducts expulsions on its own initiative.

\section{Discussion}

The study findings provide a detailed picture of the Haitian migrant population affected by expulsions, their treatment during this process, and the factors that contribute to their summary removal from the Dominican Republic. We discuss each of these aspects of the Haitian-Dominican migration system below.

\section{Significant Demographic Characteristics}

The findings both confirm and challenge several common assumptions regarding Haitians living in the Dominican Republic. Typical migrants are males, largely illiterate, in their late twenties, and employed in agricultural work. This picture is consistent with the type of Haitian labourer the Dominican and Haitian governments have actively recruited for decades to harvest sugar cane in the Dominican Republic. However, the GARR and ONM data also point to greater complexity in the composition of the Haitian population. For example, men are employed in large numbers outside of agriculture, particularly in the construction industry. The distribution of residences of Haitians throughout the country, including locations in or near cities, may facilitate employment in areas like construction and manufacturing-sectors associated with urban settings.

Families are a significant feature of the lives of Haitians in the Dominican Republic. The majority of men and women are married, though many have left their spouses in Haiti. Similarly, although the fertility rates of Haitian women in the Dominican Republic are roughly equivalent to the rates in Haiti, many women are living in the Dominican Republic without their children. These data suggest that 
Haitian migrants continue to create families with the same frequency as Haitians who remain, but that families may live divided by the border. While we did not collect data regarding the impact of migration on the quality of family and community life, this is an area that deserves greater attention. We do not know enough regarding the economic, social and cultural effects of the absence of parents and spouses on families and communities in Haiti as well as those in the Dominican Republic.

Yet there is reason to assume that families are deeply affected by migration on both sides of the border. A significant finding is the length of time that those who had been expelled had lived in the country. While there was a significant difference between ONM and GARR data in the length of time expellees lived in the Dominican Republic prior to their forced departure, this difference may simply reflect a difference in migration flows measured by ONM and GARR, respectively. However, even the ONM data suggest that Haitians in the Dominican Republic are not transitory but relocate their lives to the Dominican Republic. This picture contrasts with the temporary legal status available to Haitians, a legal category that assumes Haitians in the Dominican Republic are agricultural workers who enter the country to harvest crops and return home after the season is over. Yet the quantitative data suggest that seasonal residence tends to be the exception rather than the norm, and the picture that emerges of this population is one in which Haitians come to the Dominican Republic, settle and establish families, lives and communities. Crucially the findings suggest that their lack of regularised legal status renders Haitians living in the Dominican Republic_-both long and short term-vulnerable to human rights abuses.

\section{Migration Outflow and Due Process}

Our results suggest that the deportation process is associated with serious and widespread violations of due process and mistreatment of expellees as a class. What emerges from the study is an expulsion process in which Dominican officials attempt to identify people of Haitian origin and summarily expel them from the country. This is a key finding because the issue of due process is a central question of the study.

The findings indicate that the scope of expulsions is widespread in terms of geography as well as the depth of the population impacted. Expulsions of Haitians occur in Haitian communities throughout the country, and those expelled tend to be longer-term residents rather than recent arrivals. Significantly, during the peak outflows this trend increases; the average length of residence rises and the composition changes to include greater numbers of families. If increased repatriations were due to an increased inflow of migrants, we would expect that the average length of residence would decrease and fewer families would be included among those expelled. The GARR and ONM data suggest that increases in outflow are driven by factors other than a rise in illegal migration. Even if enforcement of migration policy was 
due to increased inflow, the data indicate that enforcement efforts are not targeted at the recent arrivals, but rather towards established communities of Haitians.

So, as more established communities are targeted, more women and children are expelled. Despite the bilateral agreement that stipulates that the Dominican Republic will seek to avoid separation of families, the study indicates that family separation remains a significant problem. This finding has important social, policy and legal implications. The expulsion of Dominican-born children of Haitian parents presents serious legal issues. Between 4 and 8 per cent of the total number of individuals expelled were born in the Dominican Republic, as were a majority of the child expellees. While Dominican migration officials justify expulsion of children on the grounds that their parents are illegal, these offspring are entitled to Dominican nationality under domestic law and therefore have a claim to remain in their homeland. Yet Haitian parents of children born in the Dominican Republic find it extremely difficult to obtain birth certificates for their children, as authorities require proof of legal residence of the parent in order to issue a birth certificate (Human Rights Watch 2002). We do not know how many expelled children possessed Dominican birth certificates, but only 4 per cent of total GARR respondents reported carrying Dominican identity documents. As a matter of policy, Dominican officials argue that they are keeping families together by expelling Dominican-born children along with their Haitian parents-regardless of whether the children possess Dominican birth certificates. This ignores the possibility that legal entitlement of these children to Dominican nationality might require the family to remain intact in the country. ${ }^{7}$

Significantly, the study did not identify any specific criteria government officials use to select individuals for expulsion. We do not know why officials selected any particular individual, and individual victims were unable to identify why they had been arrested, other than that the authorities thought they were Haitian. Indeed, as we have shown, quantitative data indicate a considerable diversity exhibited within the population with regard to expellees' age, occupation and period of residency in the Dominican Republic. This suggests that all Haitians (or those of Haitian appearance) are vulnerable to summary expulsion. This is consistent with the finding that a great majority of those expellees were arrested outside bateys or at work. The suggestion by several key informants that Haitians who leave the bateys become more visible, and therefore more vulnerable to arrest and expulsion by officials, is supported by the GARR and ONM data. Thus public visibility of Haitians is a salient risk factor for summary expulsion and suggests that Haitians (and those whom the authorities suspect of being Haitians) as a class are vulnerable to expulsions.

Officials appear to assume that Haitians without documentation lack legal authorisation to remain in the country, thereby using lack of documentation as a proxy for eligibility of deportation. The study found that few expellees (less than 10 per cent) had documents. However, there were no data regarding the reasons for the lack of identity papers. The Haitian government does not have a robust system in place to provide identity documents routinely to all its nationals, a problem that compounds the difficulties Haitian migrants face in securing legal entitlements once in the 
Dominican Republic. In addition, human rights groups have reported that many Haitians in the Dominican Republic are entitled to, but never receive, legal documents for which they are eligible (Human Rights Watch 2002; National Coalition for Haitian Rights 1995). In theory these individuals should be able to establish their legal status if the Dominican government conducted individualised deportation hearings with appropriate due process guarantees, though lack of Haitian identification poses additional evidentiary challenges.

The study suggests that the presumption of illegality has far-reaching effects. The GARR data indicate that those arrested are taken directly into custody and expelled from the country without the opportunity even to collect their belongings, a finding which the migration department corroborated. In addition, the decrease during expulsion peaks in numbers of expellees who are imprisoned before they are removed may be an indication that the administrative capacity of the Dominican migration infrastructure breaks down under the strain of increased numbers of expulsions. The government may transport expellees directly to the border rather than holding them first in prisons. In either situation, expellees are deprived of their possessions. Further, 10 per cent of migrants report beatings by government agents in the course of their expulsion.

Clearly, the manner in which Dominican authorities conduct deportations of Haitians deprives individuals of humane treatment. Our results raise serious concerns regarding adherence to domestic and international due process guarantees. They also raise important questions about the links between the lack of documentation and human rights abuses.

\section{Antecedent Causes to Expulsions}

In addition to finding that the Dominican government enforces its migration policy in a manner that results in widespread human rights violations of Haitian expellees, the study identified several antecedents to this occurrence, including a history of anti-Haitian sentiment, unequal power relations between Haiti and the Dominican Republic, and support for an economy of trafficking Haitians to the Dominican Republic. Scholars, political analysts and human rights activists have discussed these factors prior to our study (Catanese 1999; Corten and Duarte 1995; Human Rights Watch 2002; Martinez 1995, 1999; Murphy 1991; National Coalition of Haitian Rights 1995; Wilhelms 1994). Although these issues were not the primary focus of our study, we find them very important. Our data corroborate these prior reports and suggest that these factors continue to be relevant to Haitian migration. We discuss below the ways in which each of the three antecedents listed above manifested itself in our study, to achieve a fuller understanding of the political economy of migration between the two countries.

\section{Anti-Haitian Sentiment}

An important theme that emerges from our study is the prevalence of a deeply ingrained anti-Haitian bias within Dominican society. Both the literature regarding 
Haitian migration (Ferguson 1992; National Coalition of Haitian Rights 1995; Wilhelms 1994) and the key informants in the study discuss the influence of anti-Haitian bias in the Dominican Republic. We found that history, the press and Dominican stakeholders constitute different dimensions of this issue. Together, they are a significant barrier to achieving the substantive changes in Dominican migration policy and practice that would improve the treatment of Haitians in the country.

Scholars have noted that, as a group, Haitians in the Dominican Republic are scorned for their African heritage, in a country that clings furiously to its Spanish and European roots (Corten and Duarte 1995; Murphy 1991; Wilhelms 1994). Political and opinion leaders continue to invoke the Haitian occupation of the country during 1822-44 to justify fears of a Haitian take-over and encourage anti-Haitian sentiment. Anti-Haitian bias affects NGOs in the Dominican Republic working to promote Haitian rights; groups cite fear that their advocacy may provoke a violent state-sanctioned backlash as an inhibitor of their efforts on behalf of Haitians.

Another theme that emerged in the study is the role that the press plays in framing public discussion of Haitian issues. Our review of press coverage of stories regarding Haitians, particularly of the legal case regarding deportation pending in the InterAmerican System, indicates that reporting is not balanced. Nationalist, anti-Haitian perspectives receive prominent attention and key informants working with the Haitian population report finding it difficult to make their voices heard through the public media.

For example, the press liberally covered the episodes of mass expulsions of Haitians in the 1990s. Both President Balaguer and later President Leonel Fernandez who unseated him, initiated expulsions (in 1991 and 1996-97, respectively) in a political climate steeped with heated nationalist debate about the presence of Haitians in the country. ${ }^{8}$ Yet the study found the media did not publish reports of all peak outflows. Further research needs to be conducted on this. However, we suspect that sporadic coverage may have several consequences. First, coverage of 'political' expulsions may help give them symbolic significance within the country: the government crackdown and removal of illegal Haitians becomes linked to the political, economic and cultural defence of the nation. Second, the fusion of expulsions and national defence may make it difficult for civil society to garner support for the rights of Haitians. Public debate of the issue becomes framed as a choice between support of the country and support of those (Haitians) who threaten it. Finally, selective press coverage renders invisible the expulsions of Haitians that take place daily and thus helps to mask the structural aspects of Dominican migration practice and the human rights abuses it generates.

Our interviews also suggest that anti-Haitian bias is prevalent among the stakeholders and decision-makers of policy on issues affecting Haitians. The finding of bias suggests that state policy-makers and those who implement it may exercise their authority in a manner adverse to Haitians. This hypothesis is supported by the current interpretation and implementation of migration laws to effect summary expulsions. Other key informants cited negative public opinion of Haitians as a 
constraint on the actions they could initiate or the opinions they could express in support of Haitians. It could be that some in this group actually harboured anti-Haitian biases, but justified their behaviour based on external attitudes. Nevertheless, our data indicate that popular views regarding Haitians influence government officials and prominent figures in public life. This does not bode well for the prospects of improving the status and treatment of Haitians in the country. Given the violent history, pervasive nature and strength of anti-Haitian sentiment, the opportunities to promote a public dialogue in which the positive contributions of Haitians can be recognised and valued are extremely limited. If public speakers will not advocate improved human rights conditions for Haitians, where and how will private individuals begin to change their attitudes toward Haitians in their communities?

\section{Power Disparities between Haiti and the Dominican Republic}

The Dominican Republic and Haiti are and always have been interdependent, for a variety of geographical, historical, economic and social reasons. Increased interdependence, however, has not been commensurate with equal power. Similar to anti-Haitian bias, the study identified power disparities between Haiti and the Dominican Republic as a factor that contributes to expulsions. In particular, the data suggest that power imbalances operate at the level of state relations and policy implementation. These inequities, in turn, are components of the framework for individual interchange between Haitian migrants and Dominican authorities. Thus, the abstract level of state-to-state relations is linked to the experiences of Haitians subject to the expulsion process.

Today, the Dominican Republic's economy is the fastest growing in Latin America, while Haiti's is the poorest (World Bank 2002a and b). All poverty indicators in the Dominican Republic are improving: 83 per cent of Dominicans are literate and life expectancy is at 71 years. In contrast, less than half of adult Haitians are literate and life expectancy is only 54 years. The power disparities between the two countries influence the ability of the Haitian government to improve the way in which the Dominican government treats Haitians in the country.

For example, Haitian government officials and other key informants frequently remarked that the Dominican migration (and other) officials often disregard-without sanction-agreed deportation procedures, such as providing lists to Haitian officials of those whom the government is removing. ${ }^{9}$ Outside of the peaks in international interest during mass collective expulsions, Haitian government officials do not appear to exercise diplomatic or political pressure to protect Haitian migrants. Thus the role of Haitian officials involved with outflows is essentially a passive one of providing humanitarian assistance to those removed from the Dominican Republic, leaving the daily abuses associated with expulsions unremedied by the state. 


\section{The Political Economy of Trafficking}

The study also identified the existence of a political economy of Haitian migration to the Dominican Republic that contributes to expulsions. The primary aspects of this system include: the status of the Haitian economy and Haitian migrants; Dominican private employers; a political climate in the Dominican Republic which is hostile to Haitians; Dominican enforcement of immigration laws and policies; and corrupt Dominican officials. These components inter-relate and influence one another, yet are not necessarily tightly or centrally coordinated. In fact, the system may be more robust precisely because it does not depend on the various actors within it to be aware of the actions of others. Rather, the dynamic is one in which each aspect of the system operates independently, yet contributes to maintenance of the whole. The study suggests that the Haitian-Dominican migration system facilitates current migration enforcement practices and the human rights breaches associated with them. Whilst we have begun to elucidate these links, further research in this area is needed to increase our understanding of the complex nature of migration between the two countries.

The quantitative data corroborate prior research that indicates Haitians who search for work in the Dominican Republic are among the former country's poorest citizens (Martinez 1995). Mostly illiterate and in need of economic support, these migrants are ill-equipped to navigate the bureaucratic requirements to obtain valid work authorisation permits. The majority of migrants do not possess identity documents from the Haitian government and must rely primarily on Dominican employers and officials to facilitate their compliance with the legal requirements for employment. Thus the relatively low level of human resources of this group makes them vulnerable to exploitation.

Indeed, the study indicates that Dominican employers take advantage of their Haitian workforce. The lack of legal documentation of the expellees-virtually all of whom report they were working-suggests that Dominican employers are not assisting their Haitian workers to obtain proper papers. In addition, some informants report coordination between employers and government officials to expel workers before they are able to collect their wages. Further, while a significant number of expellees were arrested at work, there were no data to suggest that employers intervened to prevent the removal of employees. More investigation is needed, but this finding raises concerns that employers actively collude with, or passively benefit from, Dominican migration enforcement policies.

The pervasive social and political hostility toward Haitians in the country contributes to the ability of employers of Haitian workers to set terms and conditions of employment unilaterally, and impedes migrant workers from holding private actors accountable for mistreatment. The short-term interests of employers in maintaining a supply of low-wage labour conflict with the interests of Haitian workers to improve their working conditions. Rather, for Haitian migrant workers, labour relations play out in a hostile political climate, one that impedes their ability to effect change. Simply put, Haitian migrant workers are not eligible to vote in elections and the nationalist politics of the dominant political parties constricts 
public debate as well as inhibits efforts to establish mechanisms to safeguard the rights of Haitians. While there are organisations that serve Haitian communities in the Dominican Republic, there are no strong political constituencies campaigning for their rights. This suggests that legal reform that would increase enforcement of Haitian rights will not be generated from within civil society, in the absence of substantial changes in the political landscape.

The political climate also contributes to the ability of Dominican authorities to operate with virtual impunity in enforcement of migration law and policy. In addition to the systemic human rights violations against Haitians engendered by migration enforcement practices, the qualitative data indicate that individual Dominican officers abuse their authority to profit personally from their power over expellees. For example, victims and key informants reported that some Dominican army officers forced Haitians to work on their private farms for a period of days before expelling them from the country. And one informant commented that army personnel sought to be stationed along the border because these positions afforded the opportunity to augment their pay through bribes and 'informal taxes' they could levy on people and goods crossing the border.

The present migration system benefits the immediate interests of the powerful Dominican stakeholders who have close contact with Haitians. Our findings suggest that Dominican employers and government officials reap personal material gain from Haitians who have no effective recourse for unpaid wages, unfair labour practices, and summary arrest and expulsion. While in the long term, the economic and political health of the country suffers when the rule of law is weak, business interests, border guards, migration officials and local army officers appear to act in their short-term and personal interests. NGOs working on Haitian issues report receiving strong public criticism of their efforts and have been unable to reorient the basic social perspective of Dominicans on this issue.

Haitians in the Dominican Republic, lacking legal status and bearing the brunt of Dominican nationalist policies, are least able to demand better treatment from Dominican authorities. At the same time, Haitian officials and key informants agree that the Haitian government seeks to promote economic growth with the goal of, over time, reducing migration to the Dominican Republic. This prioritisation de-emphasises public pressure on the Dominican government to reform its deportation practice. Thus the Haitian state tries to intervene when expulsions surge to the level of a humanitarian crisis, but tolerates the daily suffering of its citizens. This may reflect a policy choice based on political calculation not to provoke the Dominican government. Or, it may reflect the fact that the victims are among the most marginalised Haitians, and are thus unable to mobilise political support to protect their interests. Another possibility is that the Haitian government may be reluctant to intervene because migration of its poorest citizens alleviates demand for government services.

Thus, there is no apparent actor within the system who has the will and power to effect reform. Past interventions by the international community have had mixed results. While international attention focused on mass expulsions and other human 
rights abuses of Haitians increases political pressure on the Dominican government to alter its practices, the state has also reacted to criticism from abroad with swift reprisals against the victimised groups. The 1991 and 1999 mass expulsions were preceded by foreign condemnation of Dominican treatment of Haitians (National Coalition for Human Rights 1995). While interventions are risky, abstaining from action is not a promising option. Without foreign involvement, the migration system and its abusive effects are unlikely to be ameliorated.

\section{Conclusion}

The research presented here suggests the need for changes to improve the treatment and condition of Haitians and Dominicans of Haitian descent in the Dominican Republic. In particular, the areas of data collection, Dominican migration policy and practice, as well as the social and political attitudes toward Haitians, should be addressed. In this regard interventions by international institutions, donor countries, humanitarian organisations, and human rights advocates are critical, but the study suggests that these efforts must be carefully tailored to achieve the desired results. Because economic disparities between the Dominican Republic and Haiti will persist for sometime, attention must be paid to developing processes that will encourage respect for the rights of Haitians in the Dominican Republic. Each component of the migration system must be addressed to achieve transformation. Legal reform, while necessary to strengthen protection of Haitian migrants, is insufficient. Interventions are necessary to change the social attitudes of Dominicans toward Haiti and Haitians, so that civil society becomes a stakeholder in immigration reform. Individuals and communities within the Dominican Republic need to acknowledge and understand Haitians not as fundamentally different, but as sharing common or universal experiences and principles. Political figures should be supported to exercise leadership in this regard and to articulate a public vision of a society in which Haitians, and social diversity, are valued. Respect for the rule of law must be promoted at the individual, community and state levels. While the state may legitimately exercise its sovereign right to regulate its borders, rule of law is the lynchpin to protect against abuses and violation of human rights.

\section{Acknowledgements}

The full study on which this article is based, 'Unwelcome Guests: A Study of Expulsions of Haitians and Dominicans of Haitian Descent from the Dominican Republic to Haiti', was conducted by the International Human Rights Law Clinic at Boalt Hall and is available at www.humanrightsclinic.org. The authors gratefully acknowledge the research assistance from clinic interns Elizabeth Dahlstrom, Lisa M. Frydman, Timothy S. Griffiths, Jennifer A. Lenga, Linda C. Maranzana, Jesse S. Morgan, Angela C. Perry, Hillary Ronen and Katherine Zucca. Dr. Erik Smith led a mission to Haiti in February 2001 to identify and collect the quantitative data for 
this study. Harvey Weinstein and Patrick Ball provided important consultation and advice.

\section{Notes}

[1] Abuses of African migrants in South Africa bear striking similarities to reported abusive incidents against Haitians in the Dominican Republic. Allegations that immigration papers are destroyed and that dark-skinned South Africans are sometimes 'herded' into '[d] eportation camp[s]' during immigration sweeps have a certain resonance with issues presently under consideration (Handmaker and Parsley 2001: 46).

[2] Sugar plantations also employed large numbers of Cocolo labourers, residents of primarily English-speaking colonies in the Caribbean. While these immigrants, like Haitians, were cheaper than their Dominican counterparts, Cocolos possessed language and technical skills that enabled them to move into industrial positions on plantations, while Haitian workers occupied the lowest paid, agricultural jobs (Murphy 1991: 39-43).

[3] The selection criteria for the sample were individuals who had been expelled from the Dominican Republic between August 1999 and March 2000. In the course of interviewing respondents, researchers learned that four victims had been expelled earlier than August 1999 (in 1996, March 1999, June 1999 and July 1999, respectively). In addition, researchers interviewed one victim who had been expelled eight days prior to the interview. Although the times of expulsion were different, the experiences reported by these victims were not otherwise distinguishable from those expelled during the study period.

[4] We adjusted the GARR population counts to reflect the underenumeration of children. About 5 per cent of GARR interviews were of children age $0-14$, while 8 per cent of ONM entries were for children aged $0-14$. The low percentage of children in the GARR data seems odd since by other measures such as time in the Dominican Republic and proportion of females we would expect GARR data to contain more deported families than ONM. This low count of children in GARR may be caused by the survey instrument: GARR used a three-page interview form while ONM used an entry list format. It appears that children were not regularly interviewed by GARR. Thus counts of children based on counts of GARR interview forms are unreliable. Instead, we may count children using the GARR interviews of their parents, which report the number of children accompanying the parent in the deportation. The 127 women aged 20-39 interviewed by GARR report a total of 193 children deported with them. Therefore, the ratio of children deported per woman aged 20-39 is 1.5. Using ONM data there is a much smaller ratio of 0.5 (171 children aged 0-14 and 309 women aged 20-39) indicating that far fewer children are being deported. This difference between ONM and GARR could be due to either underreporting of children in ONM or that the migration flow measured by ONM contained far more women without children than in GARR.

[5] 'Batey' refers to the migrant worker camps, generally on or near sugar plantations, in which Haitian cane-cutters are housed.

[6] Age heaping occurs when the enumerator or respondent reports certain ages at the expense of others. For example, when enumerators guess the age of a person, they tend to report ages which end in the digits 0 or 5 .

[7] Unfortunately, this claim has not been raised by any parent or child subject to Dominican expulsion in any domestic or international legal forum. See the Special Rapporteurship on the Human Rights of Migrants (finding that no international human rights body has addressed the legality of a state removing a minor citizen along with alien parents (UN High Commissioner for Human Rights 2001).

[8] The third incident of major collective expulsions took place in October and November 1999, just after the Inter-American Commission for Human Rights released a report critical of the government's human rights treatment of Haitian migrants. 
[9] Unfortunately, it appears that no parent or child subject to expulsion from the Dominican Republic has raised this claim in any domestic or international forum (see Special Rapporteur on the Human Rights of Migrants 2001, para. 27) (stating that children born to parents with irregular legal status in states that confer nationality based on birth in the country, whose parents are forced to leave the host country are 'being denied the right to develop as a national of the State' in which they were born).

\section{References}

Catanese, A. (1999) Haitians: Migrations and Diaspora. Boulder CO: Westview.

Corten, A. and Duarte, I. (1995) 'Five hundred thousand Haitians in the Dominican Republic', Latin American Perspectives, 22(3): 94-110.

Dirección General de Migración (2000) Relacion de Nacionales Haitianos Repatriados a su Pais de Origen en el Año 1999. Santo Domingo: Secretaría de Estado de Interior y Policía, República Dominicana (mimeo).

Ferguson, J. (1992) The Dominican Republic: Beyond the Lighthouse. London: Latin America Bureau; New York: Monthly Review Press.

Handmaker, J. and Parsley, J. (2001) 'Migration, refugees, and racism in South Africa', Canada's Periodical on Refugees, 20(1): 40-51.

Human Rights Watch (2002) Dominican Republic: 'Illegal People': Haitians and Dominico-Haitians in the Dominican Republic. New York.

Inter-American Commission on Human Rights (1991) 'Situation of Haitians in the Dominican Republic', in Annual Report 1991. Washington DC: General Secretariat, Organization of American States, 255-79.

Inter-American Commission on Human Rights (1999) Report on the Situation of Human Rights in the Dominican Republic. Washington DC: General Secretariat, Organization of the American States, OEA/Ser.L./V./2.104, doc.49 rev. 1.

Inter-American Commission on Human Rights (2001) 'Second progress report of the special rapporteurship on migrant workers and their families in the Hemisphere', in Annual Report of the Inter-American Commission on Human Rights 2000. Washington DC: General Secretariat, Organization of American States, OEA/Ser./L./V./2.111, doc. 20 rev, 1415-86.

Inter-American Court on Human Rights (2000) Order of the President September 14, 2000. San Jose, Costa Rica.

Martinez, S. (1995) Peripheral Migrants: Haitians and Dominican Republic Sugar Plantations. Knoxville: University of Tennessee Press.

Martinez, S. (1999) 'From hidden hand to heavy hand: sugar, the state and migrant labor in Haiti and the Dominican Republic', Latin American Research Review, 34(1): 57-84.

Murphy, M. (1991) Dominican Sugar Plantations: Production and Foreign Labor Integration. New York: Praeger.

National Coalition for Haitian Rights (1995) Beyond the Bateyes. New York.

Salt, J. (2001) 'The business of international migration', in Siddique, M.A.B. (ed.) International Migration into the 21st Century: Essays in Honour of Reginald Appleyard. Cheltenham: Edward Elgar, 86-108.

UN General Assembly (1990) International Convention on the Protection of the Rights of all Migrant Workers and Members of their Families. New York: United Nations, Preamble: G.A. Res. 45/158, Annex, U.N. GAOR, 45th Sess., Supp. No. 49 [A] (Vol. I), 262-73.

UN High Commissioner for Human Rights (2001) Special Rapporteur on the Human Rights of Migrants: Discrimination Against Migrants—Migrant Women. UNHCHR Prep. Comm., 1st Sess., Agenda Item 7, U.N. Doc. A/CONF.189/PC.1-19.

Wilhelms, S.K.S. (1994) Haitian and Dominican Sugarcane Workers in the Dominican Bateyes: Patterns and Effects of Stereotypes and Discrimination. Munster: Lit Verlag.

World Bank Group (2002a) Dominican Republic Country Brief. Washington DC.

World Bank Group (2002b) Haiti Country Brief. Washington DC. 


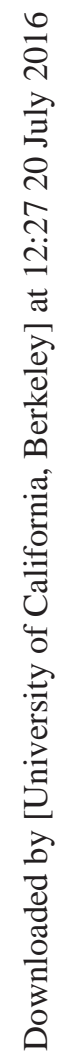

